\title{
FAKTOR-FAKTOR YANG MEMPENGARUHI TINGKAT KECEMASAN PASIEN TB PARU DI RA 3 RSUP HAJI ADAM MALIK MEDAN
}

\author{
Soep \\ Jurusan Keperawatan Poltekkes Kemenkes Medan
}

\begin{abstract}
Abstrak
Penyakit TBC sudah di kenal sejak dahulu kala. Penyakit ini di sebabkan oleh kuman /bakteri mycobacterium tuberculosis.Kuman ini pada umumnya menyerang paru-paru, seperti kelejar bening,kulit,usus/saluran pencernaan, selaput otak dan sebagainya. Kecemasan adalah respon atau pengalaman yang menyakitkan yang dialami oleh seseorang terhadap berbagai alat-alat dalam yang tunduk dibawah jaringan syaraf bebas, seperti jaringan jantung, alat pernafasan, kelenjar-kelenjar peluh, dan lainlain. Faktor-faktor yang mempengaruhi kecemasan pasien dapat berasal dari faktor internal dan eksternal. Faktor internal antara lain berupa usia, jenis kelamin, tingkat pendidikan. Sedangkan faktor eksternal berupa ancaman tarhadap integritas biologis dan ancaman terhadap konsep diri. Pengumpulan data di lakukan dengan mengunakan kuisioner. Hasil peneltian ini menunjukkan faktor-faktor yang mempengaruhi tingkat kecemasan pasian TB paru di Rumah Sakit Haji Adam Malik Medan berdasarkan usia, Jenis Kelamin, Tingkat Pendidikan. Populasi dalam penelitian ini adalah semua pasien yang ada di RA 3 dengan sampel 37 orang. pembahasan hasil penelitin bahwa responden yang menunjukkan kecenderungan memilik tingkat kecemasan, pasien yang berusia 46-50 tahun memiliki tingkat kecemasan sebanyak (35,1\%). Responden yang berjenis kelamin laki-laki memiliki tingkat kecemasan sebanyak (56,8\%). Responden yang berpendidikan SMA yang memiliki tingkat kecemasan sebanyak $(35,1 \%)$.
\end{abstract}

Kata Kunci : Tingkat Kecemasan

\section{PENDAHULUAN}

Penyakit TBC sudah di kenal sejak dahulu kala. Penyakit ini di sebabkan oleh kuman /bakteri mycobacterium tuberculosis. Kuman ini pada umumnya menyerang paru-paru, seperti kelejar bening, kulit, usus/ saluran pencernaan, selaput otak dan sebagainya.

Di Indonesia diperkirakan setiap tahunnya 150 ribuan orang meninggal akibat tuberculosis (TBC). Artinya, setiap hari ada sekitar 300 orang yang meninggal akibat TBC di Negara kita. Diperkirakan jumlah penderita di Indonesia sekitar $10 \%$ dari jumlah penderita TBC didunia. Worl Health Organization (WHO) dalam Annual Report on Global TBC control 2005 menyatakan terdapat 22 negara dikatagorikan sebagai hing-burden countries terhadap TBC. Indonesia termasuk peringkat ketiga setelah India dan China dalam menyumbang TBC di dunia. (WHO 2004).

Berdasarkan survei Kesehatan Rumah Tangga (SKRT) 2007 prevalansia angka kesakitan di Indonesia sebesar $8 / 1000$ penduduk berdasarkan gejala tanpa pemeriksaan laboratorium. Berdasarakan hasil survei Kesehatan Rumah Tangga (SKRT) tahun 2007, TBC menduduki rangking ketiga sebagai penyebab kematian (9,4 dari total kematian) setelah penyakit sistem sirkulasi dan sistem parnafasan. Hasil survei prevalensi tuberkulosis Basil Tahan Asam (BTA) positif secara nasional $110 / 100.000$ penduduk.

Bila seseorang menderita TBC, ada satu hal yang penting yang harus diperhatikan dan di lakukan, yaitu keteraturan minum obat TBC sampai dinyatakan sembuh. Pada umumnya, pengobatan panyakit TBC akan selesai dalam jangka waktu 6 bulan, yaitu 2 bulan pertama setiap hari (tahap intensif) di lanjutkan 3 kali dalam seminggu selama 4 bulan tahap lanjut. Hal ini yang secara ekonomi berhubungan dengan pendapatan keluarga, terlebih kepada keluarga yang pendapatannya rendah. Dimana dalam pengobatan TBC ini menimbulkan dampak bahwa banyak penderita TBC yang merasa bosan karena pengobatan yang lama dan pengobatan yang dirasakan mahal. Selain itu keadaan ekonomi mempengaruhi faktor fisik, kesehatan, dan pendidikan. Dimana apabila faktor tersebut cukup baik maka akan mengurangi beban fisiologis dan pisikis.

Faktor-faktor yang mempengaruhi kecemasan pasien dapat berasal dari faktor internal dan eksternal. Faktor internal antara lain berupa usia, jenis kelamin, pekerjaan, tingkat pendidikan, tingkat sosial ekonomi, dan tipe kepribadian. Sedangkan faktor eksternal berupa ancaman terhadap integritas biologis dan ancaman terhadap konsep diri.

Diperkirakan Bahwa dari populasi orang dewasa di Indonesia yang mencapai 150 juta jiwa, sekitar 11,6 persen atau 17,4 juta jiwa mengalami gangguan mental emosional atau gangguan kesehatan jiwa berupa gangguan kecemasan. Gangguan kecemasan dapat terjadi pada semua usia, lebih sering usia dewasa dan lebih banyak pada wanita. Sebagian besar kecemasan terjadi pada umur 21-45 tahun. (http://kesehatan.kompasiana.com)

Kecemasan terjadi sebagai akibat dari ancaman terhadap harga diri atau identitas diri yang sangat mendasar 
bagi keberadaan individu. Kecemasan di komunikasikan secara interpersonal dan merupakan bagian dari kehidupan sehari-hari, menghasilkan peringatan yang berharga dan penting untuk upaya memelihara keseimbangan diri dan melindungi diri.

Dilihat dari faktor sosial budaya khususnya dari segi pekerjaan. Dimana pada umumnya penderita yang bekerja mudah mengalami kecemasan karena mempunyai kesibukan, sehingga dapat memudahkan menimbulkan keluhan-keluhan dari gejala TBC. Dan mereka akan takut kehilangan pekerjaan akibat penyakit yang mereka derita. Selain itu juga takut atau cemas berinteraksi dengan orang lain. Disamping faktor ekonomi dan sosial budaya, penyebab kecemasan dapat dilihat yang penting dalam timbul kecemasannya.

Di samping itu juga pola hidup dapat mempengaruhi kecemasan pada penderita TBC. Pola kebiasaan merokok dan mengkonsumsi alkohol sangat jelas berhubungan dengan penyakit TBC. Namun dalam pengobatan TBC, salah satu unsur yang penting adalah merobah pola hidup dengan memodifikasi pola hidup seperti perbaikan nurisi, olahraga dan menghilangkan stres dan kecemasan yang timbul.

Tidak hanya itu, penderita TBC merasa cemas dan was-was tentang kepercayaan masyarakat setempat. Kepercayaan-kepercayaan lokal mengenai tuberculosis dan penyebab pasti berlainan di berbagai Negara, berbagai daerah, berbagai kebudayaan, dan bahkan pada kelompokkelompok masyarakat yang berbeda yang tinggal di dalam daerah yang sama. Agama, kasta, suku, atau tingkat pendidikan dapat mempengaruhi pendapat masyarakat. Di beberapa daerah ada masyarakat yang percaya bahwa TBC di sebabkan oleh roh jahat yang memasuki pasien. Meskipun ada pasien yang mengetahui bahwa TBC marupakan panyakti yang menular, tetapi ada yang berpendapat bahwa orang tertentu dapat kena penyakit itu karena di santet. Di daerah kabanyakan orang biasa mangira bahwa orang dapat terkena TBC dari potongan kayu yang dipakai untuk membersihkan gigi. Di tempat lain gejala tersebut sering barkaitan dengan dosa, akibat perzinahan (Sulianti 2007)

Tuberkulosis sebagian besar menyerang usia produktif antara 15 dan 45 tahun sehingga selain meningkatkan angka morbiditas dan mortalitas, penyakit ini juga menurunkan produktivitas masyarakat. Peningkatan kasus infeksi HIV/AIDS juga berkorelasi dengan peningkatan kasus tuberkulosis ini. Data menunjukkan, 3 persen dari kasus baru tuberkulosis terjadi pada pasien dengan HIV positif. Padahal, beberapa daerah memiliki insiden HIV tinggi, seperti di Papua, Kalimantan Barat, Bali, Sumatera Utara, dan Jakarta.

Gambaran tuberkulosis pada HIV kadangkadang tidak khas, terutama bila HIV-nya sudah lanjut, sehingga mungkin tidak terdiagnosis dan berdampak pada keterlambatan pengobatan. Selain itu, pemberian obat anti-TB bersamaan dengan pemberian obat antivirus (ARV) untuk menangani HIV-nya bisa meningkatkan efek samping. Itu sebabnya mengapa kematian pasien HIV lebih cepat karena infeksi tuberkulosis. (kompas 2011).
Data penderita penyakit TBC yang di peroleh dari RSUP Haji Adam Malik Medan pada tahun 20112012 menunjukan bahwa penderita TBC ada sebanyak 372 orang dan semua pasien TBC tersebut di rawat di rawat di RA 3 RSUP Haji Adam Malik Medan.

Kepedulian masyarakat terhadap penanggulangan dan pemberantasan penyakit tuberkulosis (TBC) di Indonesia, hingga saat ini masih sangat rendah. Padahal korban meninggal akibat TBC di Indonesia jumlahnya sangat fantastis, sekitar 175.000 per tahun atau sekitar 500 orang perharinya.

\section{METODE PENELITIAN}

Dalam penelitian ini, peneliti menggunakan metode deskriktif dengan desain "Cross Sectional" yaitu suatu metode yang merupakan pengamatan pada saat bersamaan (sekali waktu) yang bertujuan untuk mengetahui Faktor-faktor yang mempengaruhi tingkat kecemasan pada pasien TB paru di RA 3 RSUP Haji Adam Malik Medan 2013. Penelitian ini di lakukan di RSUP Haji Adam Malik Medan Tahun 2013. Waktu penelitian ini akan di lakukan pada bulan Februari-Juli Tahun 2013. Yang menjadi populasi dalam penelitian ini adalah penderita TBC sebanyak 372 orang yang di rawat di RA 3 RSUP Haji Adam Malik Tahun 2011-2012. Sampel dalam penelitian ini berjumlah 372 orang. Cara untuk memperoleh sampel minimal menurut Arikunto (2006) adalah bila populasi lebih dari 100 maka

pengambilan sampel sekitar $10-15 \%$ dan $20-25 \%$ dari total popolasi, dimana popolasi berjumlah 372 orang, dan peneliti mengambil $10 \%$ dari total populasi.

Jenis data yang digunakan dalam penelitian ini adalah data primer yaitu kuisoner yang berisikan pertanyaannya sesuai dengan variable yang diteliti. Sedangkan data lain (data sekunder) di peroleh dari RSUP Haji Adam Malik Medan. Data di kumpulkan dengan menggunakan kuisoner yang dalam penelitian ini merupakan data primer. Sebelum responden mengisi kuisoner, responden di minta kesediannya untuk menyatakan persetujuan menjadi responden dalam penelitian ini, yang dilampirkan bersama dengan kuisoner oleh keluarga maupun peneliti dan peneliti menanyakan hal-hal yang kurang dimengerti responden. Setelah itu semua pertanyaan dijawab, peneliti mengumpulkan kembali lembar jawaban responden, dan mengucapkan terima kasih atas kesediannya menjadi respondent.

\section{HASIL DAN PEMBAHASAN}

\section{Hasil Penelitian}

\section{Analisis Univariat}

Dari hasil observasi berdasarkan usia diperoleh responden dengan usia 26-35 tahun yaitu sebanyak 7 responden $(18,9 \%)$, responden yang berusia 36-45 tahun sebanyak 10 responden $(27,0 \%)$, responden yang berusia 46-50 tahun sebanyak 13 responden $(35,1 \%)$, dan responden yang berusia 50 tahun ke atas sebanyak $(18,9 \%)$. Jenis kelamin responden laki-laki sebanyak 21 orang $(56,8 \%)$, dan responden yang berjenis kelamin perempuan sebanyak 16 orang $(43,2 \%)$. Responden dengan tingkat pendidikan SD sebanyak 1 
orang (2,7\%), SMP sebanyak 5 orang $(13,5 \%)$, SMA sebanyak 13 orang $(35,15)$, AKADEMI sebanyak 11 orang $(29,7 \%)$, dan responden dengan pendidikan S1 sebanyak 7 orang $(18,9 \%)$.

\section{Analisis Bivariat}

\begin{tabular}{|c|c|c|c|c|c|c|c|}
\hline Tab & 1. Dist & & Frekue & & raasa & & USia \\
\hline & Res & onden & Yang & & miliki & & ingkat \\
\hline & Kec & masan & Di RA & RSUI & Haji & daI & \\
\hline & Mec & & n 2013 & & & & \\
\hline & & & ingkat Ke & emasan & & & mlah \\
\hline No & Usia & Ringan & Sedang & Berat & Panik & $\mathbf{F}$ & $\%$ \\
\hline 1 & $26-35$ & 1 & 1 & 5 & - & 7 & $18,9 \%$ \\
\hline & Tahun & & & & & & \\
\hline 2 & $36-45$ & 0 & 1 & 6 & 3 & 10 & $27,0 \%$ \\
\hline & Tahun & & & & & & \\
\hline 3 & $46-50$ & 1 & 3 & 7 & 2 & 13 & $35,1 \%$ \\
\hline & Tahun & & & & & & \\
\hline 4 & 50 tahun & 1 & 1 & 5 & 0 & 7 & $18,9 \%$ \\
\hline & ke atas & 3 & 6 & 23 & 5 & 37 & \\
\hline
\end{tabular}

Dari tabel 1 di atas dapat diketahui bahwa berdasarkan usia responden yang memiliki tingkat kecemasan terhadap penyakit TB paru diketahui mayoritas responden berusia 46-50 tahun memiliki tingkat kecemasan berat sebanyak 7 responden dari 13 responden $(35,1 \%)$, diikuti usia 36-45 tahun mayoritas responden dengan tingkat kecemasan berat sebanyak 6 responden dari 10 responden $(27,0 \%)$, serta usia 26-35 tahun dan 50 tahun ke atas masing-masing memiliki tingkat kecemasan mayoritas 5 responden dari 7 responden $(18,9 \%)$.

Tabel 2. Distribusi Frekuensi Berdasarkan Jenis Kelamin Responden Yang Memiliki Tingkat Kecemasan Di RA 3 RSUP Haji Adam Malik Medan Tahun 2013

\begin{tabular}{ccccccccc}
\hline \multirow{2}{*}{ No } & Jenis & \multicolumn{3}{c}{ Tingkat Kecemasan } & \multicolumn{2}{c}{ Jumlah } \\
& Kelamin & Ringan & Sedang & Berat & Panik & F & \% \\
\hline 1 & Laki-laki & 2 & 3 & 12 & 4 & 21 & $56,8 \%$ \\
2 & Perempuan & 1 & 3 & 11 & 1 & 16 & $43,2 \%$ \\
\hline & Jumlah & 3 & 6 & 23 & 5 & 37 & $100 \%$ \\
\hline
\end{tabular}

Dari tabel 2 di atas dapat diketahui bahwa berdasarkan jenis kelamin responden yang memiliki tingkat kecemasan terhadap penyakit TB Paru mayoritas laki-laki memiliki tingkat kecemasan berat sebanyak 12 orang dari 21 responden (56,8\%), dan minoritas perempuan dengan tingkat kecemasan berat sebanyak 11 responden dari 16 orang $(43,2 \%)$.

Tabel 3. Distribusi Frekuensi Berdasarkan Tingkat Pendidikan Responden Yang Memiliki Tingkat Kecemasan Di RA 3 RSUP Haji Adam Malik Medan Tahun 2013

\begin{tabular}{clcccccc}
\hline \multirow{2}{*}{ No } & $\begin{array}{c}\text { Tingkat } \\
\text { Pendidikan }\end{array}$ & \multicolumn{3}{c}{ Tingkat Kecemasan } & \multicolumn{2}{c}{ Jumlah } \\
& Ringan & Sedang & Berat & Panik & F & \% \\
\hline 1 & SD & 0 & 0 & 0 & 1 & 1 & $2,7 \%$ \\
2 & SMP & 1 & 0 & 4 & 0 & 5 & $13,5 \%$ \\
3 & SMA & 1 & 3 & 8 & 1 & 13 & $35,1 \%$ \\
4 & AKADEMI & 1 & 1 & 7 & 2 & 11 & $29,7 \%$ \\
5 & S1 & 0 & 2 & 4 & 1 & 7 & $18,9 \%$ \\
\hline & Jumlah & 3 & 6 & 23 & 5 & 37 & $100 \%$ \\
\hline
\end{tabular}

Dari tabel 3 di atas, dapat diketahui bahwa berdasarkan tingkat pendidikan responden yang memiliki tingkat kecemasan terhadap penyakit TB paru mayoritas tingkat pendidikan SMA dengan tingkat kecemasan berat sebanyak 8 responden dari 13 responden $(35,1 \%)$ diikuti pendidikan Akademi dengan tingkat kecemasan berat sebanyak 7 responden dari 11 orang $(29,7 \%)$, pendidikan SMP dan S1 dengan tingkat kecemasan berat masingmasing 4 responden dari $5(13,5 \%)$ dan 7 responden $(18,9 \%)$, sedangkan responden dengan pendidikan SD hanya $1(2,7 \%)$ responden dan memiliki tingkat kecemasan panik.

\section{Pembahasan}

Berdasarkan hasil penelitian yang telah dilakukan terhadap 37 responden yang memiliki tingkat kecemasan terhadap penyakit TB paru dari tabel 1 dapat diketahui bahwa berdasarkan usia responden yang memiliki tingkat kecemasan terhadap penyakit TB paru diketahui mayoritas responden berusia 46-50 tahun memiliki tingkat kecemasan berat sebanyak 7 responden dari 13 responden $(35,1 \%)$.

Usia merupakan salah satu faktor internal yang berkontribusi terhadap timbulnya kecemasan pada orang tua, Bahkan ada yang berpendapat bahwa faktor usia muda lebih mudah mengalami cemas daripada usia tua, tetapi ada juga yang berpendapat sebaliknya (Kaplan \& Sadock).

Dari tabel 2 dapat dilihat bahwa jenis kelamin responden yang memiliki tingkat kecemasan terhadap penyakit TB Paru mayoritas laki-laki memiliki tingkat kecemasan berat sebanyak 12 orang dari 21 responden $(56,8 \%)$.

Laki-laki lebih cenderung mengalami kecemasan dibandingkan dengan perempuan, hal ini dikarenakan lakilaki dirasa lebih sensitif terhadap permasalahan, sehingga mekanisme koping laki-laki lebih kurang baik dibandingkan perempuan. Hal ini ditegaskan pada hasil penelitian ini yang menunjukkan bahwa laki-laki lebih menempati posisi tingkat kecemasan dibandingkan perempuan.

Dari tabel 3 di atas dapat dilihat bahwa berdasarkan tingkat pendidikan responden yang memiliki tingkat kecemasan terhadap penyakit TB paru mayoritas tingkat pendidikan SMA dengan tingkat kecemasan berat sebanyak 8 responden dari 13 responden $(35,1 \%)$.

Makin tinggi pendidikan seseorang makin mudah menerima informasi sehingga makin banyak pula pengetahuan yang dimiliki. Sebaliknya pendidikan yang kurang akan menghambat perkembangan sikap seseorang terhadap nilai-nilai yang baru diperkenalkan Status pendidikan dan status ekonomi yang rendah pada seseorang menyebabkan orang tersebut mengalami stres dibanding dengan mereka yang status pendidikan dan status ekonomi yang tinggi.

\section{KESIMPULAN DAN SARAN}

\section{Kesimpulan}

Berdasarkan hasil penelitian terhadap 37 responden menunjukkan bahwa responden cenderung memiliki tingkat kecemasan berat. Hal dapat ditunjukkan 
bahwa dari 13 responden $(35,1 \%)$ usia 46-50 tahun sebanyak 7 responden memiliki tingkat kecemasan berat, dari 16 responden $(43,2 \%)$ dengan jenis kelamin laki-laki sebanyak 11 responden memiliki tingkat kecemasan berat, dan dari 13 responden $(35,1 \%)$ dengan tingkat pendidikan SMA sebanyak 8 responden memiliki tingkat kecemasan berat.

\section{Saran}

Bagi keluarga yang memiliki pengetahuan cukup, diharapkan lebih meningkatkan pengetahuannya untuk mengurangi rasa cemas pasien. Bagi pendidikan keperawatan perlu ditingkatkan pengetahuan agar dapat mengukur tingkat kecemasan pasien, sehingga pasien lebih merasa tenang lagi. Bagi petugas kesehatan, diharapakan kepada petugas kesehatan supaya memberikan penyuluhan tentang cara mengurangi rasa cemas pada pasien.

\section{DAFTAR PUSTAKA}

Alsagaff dan Mukty, 2005, Dasar Dasar Ilmu Penyakit Paru, Airlangga, Surabaya.

Aditama, Tjandra Yoga, 2002, Tuberkulosis Paru, Diognosa, Terapi, Dan Masalahnya, ikatan dokter: Jakarta.

Arikunto, S, 2006, Prosedur Penelitian : Suatu Pendekatan Praktek. Edisi Revisi, Jakarta.

Crofton J, Horner N, 2002, Tuberkulosis Klinis, Cetakan I, Widya Medika: Jakarta
Danusantoso, Halim,2003, Ilmu Penyakit Paru, Hipokrates: Jakarta.

Depkes RI, 2007, Pedoman Nasional Penanggulangan Tuberkulosis,

Departemen Kesehatan RI: Jakarta.

Hawari D, 2001, Manajemen Stress, cemas dan depresi, Fakultas Kedokteran Universitas Indonesia: Jakarta.

Hudoyo Ahmad, 2008, Tuberkulosis Mudah Diobati, Fakultas Kedokteran Universitas Indonesia : Jakarta

Notoatmojo Soekidjo, 2002, Metode Penelitian Kesehatan, Rinenka Cipat: Jakarta.

Nursalam, 2003, Konsep Dan Penerapan Metedologi Penelitian Ilmu Keperawatan, Salemba Medika : Jakarta

Suliswati,dkk, 2005,Konsep Dasar Keperawatan Kesehatan Jiwa, EGC: Jakarta.

Suliwati, Taufan, 2004, Pengobatan Tuberkulosis Paru Masih Menajdi Masalah, Jakarta.

Soekanto Soerjono, 2006, Sosiologi Suatu Pengantar, Raja Grafindo Persada: Jakarta. 